\title{
ASSESSMENT OF PHYSICO-CHEMICAL PARAMETERS OF TSAEDA AGAM RIVER IN MEKELLE CITY, TIGRAY, ETHIOPIA
}

\author{
Kidu Mezgebe ${ }^{1}$, Abraha Gebrekidan ${ }^{2, *}$, Amanual Hadera ${ }^{2}$, Yirgaalem Weldegebriel ${ }^{3}$ \\ ${ }^{1}$ Department of Chemistry, Faculty of Natural and Computational Sciences, Axum University, \\ P.O. Box 1010, Axum, Ethiopia \\ ${ }^{2}$ Department of Chemistry, College of Natural and Computational Sciences, Mekelle University, \\ P.O. Box 231, Mekelle, Ethiopia \\ ${ }^{3}$ Ezana Analytical Laboratory, Ezana Mining Development PLC, P.O. Box 788, Mekelle, \\ Ethiopia
}

(Received January 30, 2014; revised August 8, 2015)

\begin{abstract}
The present work was conducted to assess the physico-chemical parameters of Tsada Agam River found in Mekelle, Tigray, Ethiopia and determine its suitability for domestic and irrigation purposes. Water samples were collected monthly for two consecutive months (February to March, 2013) at four sampling sites and analyzed for various physico-chemical parameters. The study indicated that the mean value of studied parameters, except electrical conductivity, total dissolved solids, turbidity, total alkalinity, calcium ion, sulphate ion, and total phosphorus of the river water samples were within the permissible limit of WHO for drinking water. The findings also showed the mean value of studied parameters, except sulphate ion concentration, were within the permissible limit of FAO for irrigation water. Therefore, the river water was found to be unfit for human consumption and was found to be safe and utilizable for irrigation purposes. If the quality management was properly maintained, the Tsaeda Agam River water could be utilized for a wide range of applications such as drinking and irrigation.
\end{abstract}

KEY WORDS: Physico-chemical, Pollution, Irrigation, Tsaeda Agam River

\section{INTRODUCTION}

Water is essential to all forms of life. It is indispensable for agriculture, manufacturing, transportation and many other human activities. Despite its importance, water is the most poorly managed resource in the world [1] and contaminated by several sources. Due to increasing of various human activities and some natural processes, the quality of water is decreasing continuously and is posing a great threat to all forms of life including humans [2].

Point and non-point source pollution are major environmental problems affecting water quality. The situation is worsened by lack of treatment for domestic wastes. In farming areas, the routine application of agricultural fertilizers is the major source of contamination [3, 4]. In urban areas, the careless disposal of industrial effluents and other wastes may contribute greatly to the contamination and poor quality of the water $[4,5]$.

Rivers are the main sources of both drinking water and irrigation for agriculture. They also play vital roles in transportation, maintaining soil fertility, the development of forest resources, and conservation of wild life [6]. In urban areas, the inappropriate disposal of industrial effluents and other municipal wastes may contribute greatly to the poor quality of river water. Thus, most of the rivers in urban areas of developing countries are the end point of effluents discharged by industries and municipal discharges [7, 8].

Nowadays, developing countries including Ethiopia are experiencing rapid urban and industrial growth and this makes environmental conservation a difficult task. Among this, Mekelle is the capital city of Tigray regional state, Ethiopia and it is experiencing poor quality of municipal waste disposal techniques. Apart from natural factors influencing water quality, human activities such as domestic and agricultural practices impact negatively to the quality of river water.

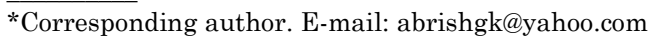


Regular monitoring of the physico-chemical parameters of water bodies have been carried out for decades in different developed countries [9-14]. Assessments of general water quality and dissolved metals concentrations in aquatic ecosystems have been extensively conducted [15-20]. However, there are limited studies of water quality and pollution status of rivers in developing countries [5, 9].

Tsaeda Agam River, which is found in Mekelle, Tigray, Ethiopia, as many other rivers receives disposal of domestic and industrial wastes. Besides, the river is used for car washing and various domestic activities. But, to the best of our knowledge no research was conducted on its water quality. Thus, the main objectives of the present study were (i) to determine the physico-chemical parameters of the river such as temperature, $\mathrm{pH}$, electrical conductivity (EC), turbidity (TUR), dissolved oxygen (DO), biochemical oxygen demand (BOD), chemical oxygen demand (COD), total solid (TS), total dissolved solids (TDS), total suspended solids (TSS), total alkalinity (TA), total hardness (TH), calcium $\left(\mathrm{Ca}^{2+}\right)$, magnesium $\left(\mathrm{Mg}^{2+}\right)$, chloride $\left(\mathrm{Cl}^{-}\right)$, sulphate $\left(\mathrm{SO}_{4}{ }^{2-}\right)$, nitrate $\left(\mathrm{NO}_{3}{ }^{-}\right)$, ammonia $\left(\mathrm{NH}_{4}^{+}\right)$, nitrite $\left(\mathrm{NO}_{2}^{-}\right)$, total nitrogen $(\mathrm{TN})$, phosphate $\left(\mathrm{PO}_{4}{ }^{3-}\right)$, total phosphorus(TP) and (ii) to generate the baseline information of the physico-chemical parameters and determine its suitability for various domestic and irrigation purposes of the river.

\section{EXPERIMENTAL}

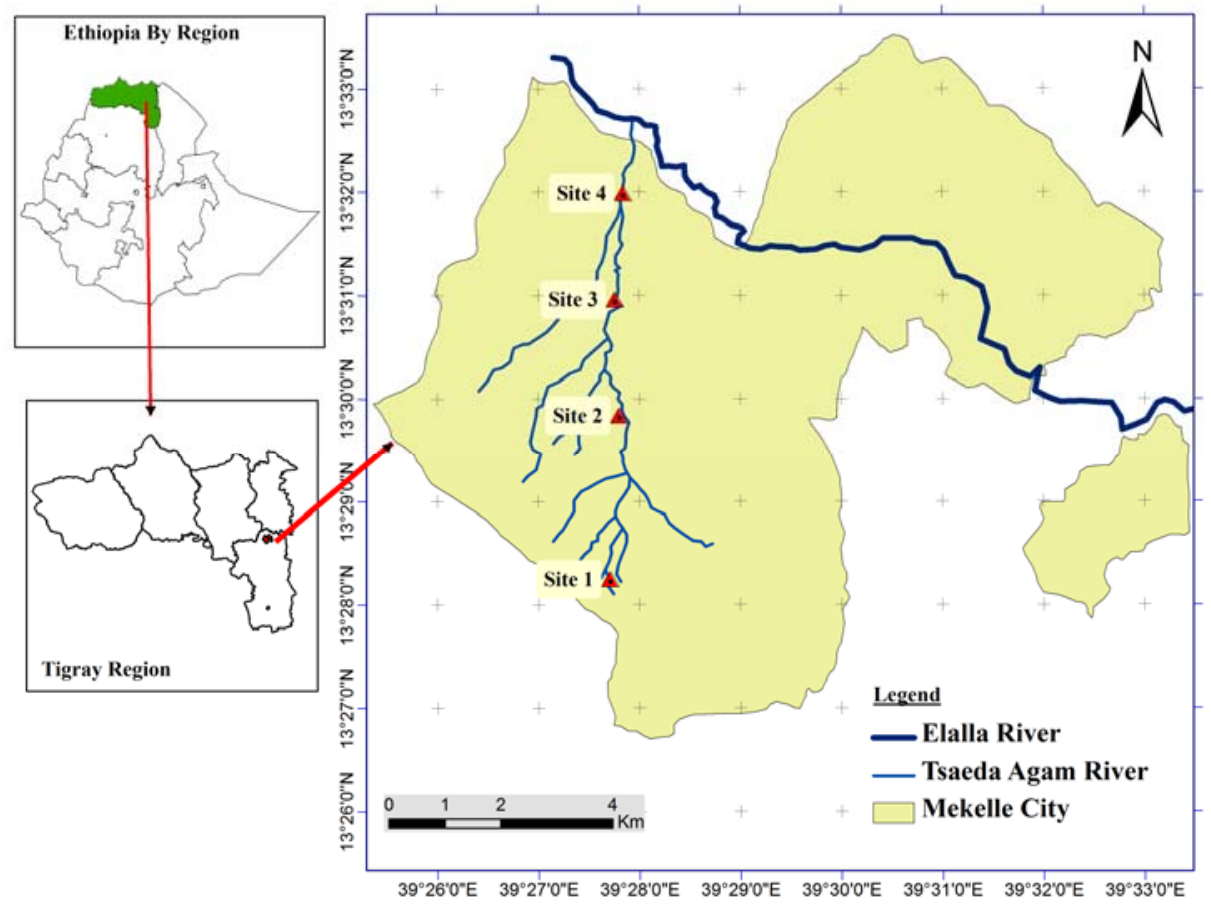

Figure 1. Map of the four sampling sites of Tsaeda Agam River. 
Description of study area

The study was carried out in Tsaeda Agam River, in and around Mekelle, Tigray, Ethiopia. The city is one of the fastest growing urban areas in Ethiopia. The climate of the region is generally sub-tropical with an extended dry period of nine to ten months and a maximum effective rainy season of 50-60 days [21]. Considering the rainfall, atmospheric temperature and evapotranspiration, more than $90 \%$ of the region is categorized as semi-arid. This makes artificial irrigation using river water an attractive option for the region. The four sampling points of the study area were randomly selected using GPS (global positioning systems) (Figure 1): Site 1, approximately the sources of the river; Site 2, a market place near to the river; Site 3, a place where the river receives a liquid waste from Ayder Referral Hospital and Site 4, place where the river leaves the city.

\section{Instruments and chemicals}

A drying oven with forced air and timer, HQ40d Multimeter (HACH LANGE, NV), Spectrophotometer (HACH DR/2800), COD Digestion reactor (HACH LANGE LT200), Turbidity meter (Turner designs Aquafluor 8000-001), UV-Visible photometer Lambada EZ201 (PerkinElmer, Australia), Analytical balance (LARK, LA114), Incubator (DIN6647/6648, Lovibond, Germany), Fume Hood Uethe-Hangsen (Uethe-Hangsen, Germany) were used during the analysis. All chemicals used were of high purity and analytical grade. At all times, fresh reagents were used and great care was taken to avoid chemical contamination.

\section{Sample collection}

A water sample from Tsaeda Agam River was collected following standard procedure as described by APHA [22]. Pre-cleaned plastic bottle was used to collect water sample for the physico-chemical analysis. Sample containers were labeled on the field using appropriate codes and water samples were temporary stored in ice packed cooler and transported to the laboratory and stored in a refrigerator at about $4{ }^{\circ} \mathrm{C}$ prior to analysis [22]. These samples were collected on a monthly basis consecutively for a period of two month (February 2013 to March 2013).

\section{Sample analysis}

The physico-chemical parameters such as temperature, $\mathrm{pH}$, electrical conductivity (EC), turbidity (TUR), total solids (TS), total dissolved solids (TDS), total suspended solids (TSS), dissolved oxygen (DO), biological oxygen demand (BOD), chemical oxygen demand (COD), total alkalinity (TA), total hardness (TH), calcium ion $\left(\mathrm{Ca}^{2+}\right)$, magnesium ion $\left(\mathrm{Mg}^{2+}\right)$, chloride $\left(\mathrm{Cl}^{-}\right)$, sulphate $\left(\mathrm{SO}_{4}{ }^{2-}\right)$, nitrate $\left(\mathrm{NO}_{3}{ }^{-}\right)$, ammonium $\left(\mathrm{NH}_{4}{ }^{+}\right)$, nitrite $\left(\mathrm{NO}_{2}{ }^{-}\right)$, total nitrogen $(\mathrm{TN})$, phosphate $\left(\mathrm{PO}_{4}{ }^{3-}\right)$ and total phosphorus (TP) were analyzed using the standard analytical methods [22, 23]. The temperature, $\mathrm{pH}$ and dissolved oxygen were determined on site using HQ40d Multimeter (HACH LANGE, NV), turbidity also determined on site using turbidity meter (Turner designs Aquafluor 8000-001). Biological oxygen demand (BOD) was measured based on oxygen consumed in a 5-d test period (5-d BOD or $\mathrm{BOD}_{5}$ ) at $20^{\circ} \mathrm{C}$ after arrival of sample to the laboratory [9]. Nutrients such as $\mathrm{NO}_{3}{ }^{-}, \mathrm{NH}_{4}{ }^{+}, \mathrm{NO}_{2}{ }^{-}, \mathrm{TN}, \mathrm{PO}_{4}{ }^{3-}$, $\mathrm{TP}$ and COD were measured by Hach Lange kits using HACH DR/2800 spectrophotometer. Standard laboratory methods as described by the APHA [9]) for the examination of water samples was employed for the analysis of TS, TSS, TDS, $\mathrm{Ca}^{2+}, \mathrm{Mg}^{2+}$ and $\mathrm{Cl}^{-}$. Suphate $\left(\mathrm{SO}_{4}{ }^{2-}\right)$ was determined using nephelometric turbidity meter [24]. 


\section{Data analysis}

All the data generated were analyzed statistically using SPSS 16.0. Reproducibility of results was regularly checked and the validated data were recorded in triplicate at the end of each experiment. Variation of each parameter between sites was analyzed using one way analysis of variance (ANOVA) at $\mathrm{p}<0.05$ level of significance.

\section{RESULTS AND DISCUSSION}

The values of different physico-chemical parameters recorded from the Tsaeda River water samples are summarized in Table 1.

Table 1. Physico-chemical parameters of Tsaeda Agam River water samples (mean \pm standard deviations).

\begin{tabular}{|c|c|c|c|c|c|c|}
\hline Parameters & Site 1 & Site 2 & Site 3 & Site 4 & WHO [25] & FAO [28] \\
\hline Temperature $\left({ }^{\circ} \mathrm{C}\right)$ & $23.6 \pm 3.1$ & $21.1 \pm 1.8$ & $20.9 \pm 2.8$ & $21.8 \pm 3.2$ & $<40$ & -- \\
\hline $\mathrm{pH}$ & $7.18 \pm 0.07$ & $7.57 \pm 0.06$ & $7.97 \pm 0.21$ & $8.13 \pm 0.09$ & 6.5-8.5 & 6.0-8.5 \\
\hline EC $(\mu \mathrm{S} / \mathrm{cm})$ & $1559 \pm 59$ & $1577 \pm 41$ & $1874 \pm 50$ & $1533 \pm 48$ & 750 & 3000 \\
\hline TUR (NTU) & $44.7 \pm 12.5$ & $50.8 \pm 16.9$ & $37.0 \pm 14.3$ & $98.2 \pm 15.5$ & 5.0 & -- \\
\hline $\mathrm{DO}(\mathrm{mg} / \mathrm{L})$ & $3.84 \pm 2.36$ & $1.47 \pm 0.37$ & $5.71 \pm 1.03$ & $10.2 \pm 0.12$ & $5.0-7.0$ & $>4.0$ \\
\hline BOD (mg/L) & $3.37 \pm 1.11$ & $5.67 \pm 1.18$ & $2.09 \pm 1.01$ & $1.8 \pm 0.4$ & $2.0-5.0$ & 8.0 \\
\hline COD (mg/L) & UMR & UMR & UMR & UMR & -- & -- \\
\hline TS (mg/L) & $1449 \pm 27$ & $1475 \pm 8$ & $1756 \pm 12$ & $1535 \pm 14$ & -- & -- \\
\hline TDS (mg/L) & $1045 \pm 27$ & $1057 \pm 28$ & $1255 \pm 33$ & $1027 \pm 32$ & 500 & 2000 \\
\hline TSS (mg/L) & $404 \pm 24$ & $419 \pm 33$ & $501 \pm .25$ & $509 \pm 20$ & -- & -- \\
\hline TA (mg/L) & $152 \pm 53$ & $331 \pm 63$ & $249 \pm 23$ & $225 \pm 35$ & 120 & -- \\
\hline $\mathrm{TH}$ (mg/L) & $483 \pm 70$ & $670 \pm 99$ & $778 \pm 44$ & $608 \pm 71$ & 300 & -- \\
\hline $\mathrm{Ca}^{2+}(\mathrm{mg} / \mathrm{L})$ & $116 \pm 11$ & $270 \pm 12$ & $243 \pm 4$ & $222 \pm 4$ & 100 & 800 \\
\hline $\mathrm{Mg}^{2+}(\mathrm{mg} / \mathrm{L})$ & $87.5 \pm 5.1$ & $104 \pm 4$ & $130 \pm 10$ & $93.8 \pm 17.1$ & 120 & 120 \\
\hline $\mathrm{Cl}^{-}(\mathrm{mg} / \mathrm{L})$ & $46.2 \pm 6.4$ & $89.8 \pm 8.8$ & $161 \pm 12$ & $100 \pm 11$ & 250 & 400 \\
\hline $\mathrm{SO}_{4}{ }^{2-}(\mathrm{mg} / \mathrm{L})$ & $519 \pm 6$ & $586 \pm 22$ & $921 \pm 22$ & $736 \pm 25$ & 250 & 400 \\
\hline $\mathrm{NO}_{3}{ }^{-}-\mathrm{N}(\mathrm{mg} / \mathrm{L})$ & $45.5 \pm 1.2$ & $36.9 \pm 0.4$ & $18.3 \pm 5.2$ & $43.9 \pm 4.4$ & 45 & 50 \\
\hline $\mathrm{NO}_{2}{ }^{-}-\mathrm{N}(\mathrm{mg} / \mathrm{L})$ & $0.13 \pm 0.07$ & $0.05 \pm 0.01$ & $0.03 \pm 0.02$ & $0.40 \pm 0.27$ & 1.0 & -- \\
\hline $\mathrm{NH}_{4}{ }^{+}-\mathrm{N}(\mathrm{mg} / \mathrm{L})$ & $0.29 \pm 0.16$ & $0.18 \pm 0.02$ & $0.16 \pm 0.01$ & $0.43 \pm 0.19$ & -- & 5 \\
\hline $\mathrm{TN}(\mathrm{mg} / \mathrm{L})$ & UMR & $99.6 \pm 0.2$ & UMR & UMR & -- & -- \\
\hline $\mathrm{PO}_{4}^{3-}-\mathrm{P}(\mathrm{mg} / \mathrm{L})$ & $0.47 \pm 0.00$ & $0.58 \pm 0.38$ & $0.07 \pm 0.00$ & $0.29 \pm 0.16$ & 0.1 & 2 \\
\hline $\mathrm{TP}$ (mg/L) & $0.26 \pm 0.20$ & $0.77 \pm 0.49$ & $0.07 \pm 0.01$ & $0.38 \pm 0.18$ & 0.1 & -- \\
\hline
\end{tabular}

UMR: under measurement range of the instrument; --: Not found.

Temperature is a factor of great importance for aquatic ecosystem, as it affects the organisms, as well as the physical and chemical characteristics of water. Water temperature obtained during the sampling period for all sites did not differ significantly at 95\% confidence level. Generally, the river temperature ranged from $20.9 \pm 2.8$ to $23.6 \pm 3.1{ }^{\circ} \mathrm{C}$ with an average value of $21.8 \pm 2.7^{\circ} \mathrm{C}$ and is found within the permissible limit of WHO [25]. This result is similar to other studies reported within the range of 19.0 to $23.9{ }^{\circ} \mathrm{C}$ [26]. Thus, the average temperature of the river is favorable for aquatic ecosystem.

$\mathrm{pH}$ indicates the intensity of the acidic or basic character of a solution and is controlled by the dissolved chemical compounds and biochemical processes in the solution [27]. It is usually monitored for assessments of aquatic ecosystem health, irrigation and drinking water sources, industrial discharges and surface water runoff. In the present study, the $\mathrm{pH}$ value shows slightly alkaline ( $\mathrm{pH} 7.18 \pm 0.07$ to $8.18 \pm 0.19$ ). These values are within the permissible limit of WHO [25] and FAO [28] set for drinking and irrigation purposes, respectively. The statistical analysis at $95 \%$ confidence level also showed no significance differences among the studied sites. 
Electrical conductivity (EC) is a measure of water capacity to convey electric current. It signifies the amount of total dissolved salts [29]. The recorded EC values for the studied sites were ranged from $1533 \pm 48$ to $1874 \pm 50 \mu \mathrm{S} / \mathrm{cm}$ which is higher than the permissible limit by WHO for drinking [25] and lower that the limit set by FAO for irrigation purposes [28]. Thus, the result indicated that the river receives high amount of dissolved inorganic substances in ionized form from their surface catchments. The statistical analysis at $95 \%$ confidence level also showed no significance differences in between the four sampling sites. The higher the EC, less water is available to plants, even though the soil may appear wet. Because plants can only transpire "pure" water, usable plant water in the soil solution decreases dramatically as EC increases. Therefore, irrigation water with high EC reduces yield potential.

In most waters, turbidity is due to colloidal and extremely fine dispersions. In many aquatic systems, water clarity is determined by the abundance of suspended algae. Eutrophic systems (containing high nutrient concentrations) support large algal populations, which reduce the clarity of the water and increase its color. In extreme cases, turbid water can harm animals and deposit heavy sediment on leaves, reducing photosynthesis [29]. Turbid water also affect how well disinfection techniques including ultraviolet light and chlorination work, and slow the establishment of vegetables. The average turbidity values of the four sampling sites were ranged from 37.0 \pm 14.3 to $98.2 \pm 15.5$ NTU. The values obtained for the Tsaeda Agame River were above the permissible limit set by WHO for drinking [25] and FAO for irrigation water [28]. The statistical analysis at 95\% confidence level indicates that Site 2 and 4 were significantly different from the other studied sites. This might be due to the proximity of the studied sites to the market and intensive agricultural areas, respectively, that receives agricultural runoff and domestic and municipal wastes. Thus, the entire river was generally polluted posing a great danger to aquatic lives and the people using it for domestic and irrigation purposes.

Dissolved oxygen play a role of regulator of metabolic activities of organisms and thus governs metabolism of the biological community as a whole and used as an indicator of tropic status of the water [30]. Concentration levels of DO below $5.0 \mathrm{mg} / \mathrm{L}$ adversely affect aquatic life [31]. Thus in the present study, DO ranged from $1.47 \pm 0.37$ to $10.2 \pm 0.1 \mathrm{mg} / \mathrm{L}$. A minimum value was recorded in Site $2(1.47 \pm 0.37 \mathrm{mg} / \mathrm{L})$ indicated that the studied site (Site 2) was susceptible to pollution due to the nearby market and a maximum value was recorded in Site $4(10.2 \pm 0.1$ $\mathrm{mg} / \mathrm{L}$ ) which may be due to self purification of the water along the course of the river.

Biological oxygen demand (BOD) measure the amount of oxygen requires by bacteria for breaking down to simpler substances of the decomposable organic matter present in any water, wastewater or treated effluent. It is also taken as a measure of the concentration of organic matter present in any water. The greater the decomposable matter present, the greater the oxygen demand and the greater the BOD values [32]. BOD in our study ranges from $1.8 \pm 0.4$ to $5.67 \pm 1.18 \mathrm{mg} / \mathrm{L}$. The BOD values of the river, except Site 2, were within the recommended values of WHO and FAO [25, 28]. Our findings also indicated that at $95 \%$ confidence level, Site 2 was significantly different from the other studied sites. The high BOD value recorded in Site 2 could be an indication of organic pollution due to the loads of wastes from the market place. Similarly, other findings also showed that a high level of BOD causes to decrease the value of dissolved oxygen in the river [33].

In the presence of high total solids, water will heat up more rapidly and hold more heat, this in turn, adversely affects aquatic life that has been adapted to a lower temperature regime. Low concentrations of total solids can also result in limited growth of aquatic organisms due to nutrient deficiencies [28]. High total solids effect the light penetration. Irrigation water quality is evaluated based upon total salt content. In this study, high value of TS was recorded in the ranges of $1449 \pm 27$ to $1756 \pm 12 \mathrm{mg} / \mathrm{L}$ which is beyond the permissible limits of WHO for drinking [25] and below the standards set by FAO for irrigation [28]. The statistical analysis at 95\% confidence level also showed significant differences among the sampling sites. Site 3 and 4 showed high amount of TS which might be due to receiving agricultural runoff containing 
fertilizer and suspended soil particles and effluent Ayder referral hospital water treatment plant indicating that there is poor waste management system in the city.

Total dissolved solids indicate the salinity behavior of water [34]. Water containing more than $500 \mathrm{mg} / \mathrm{L}$ of TDS is not considered as desirable for drinking water supplies [27]. Water with high TDS is undesirable or harmful for human and aquatic life. It may taste bitter, salty, or metallic and may have unpleasant odors. High TDS water is also less thirst quenching and interferes with the taste of foods. Some of the individual mineral salts that make up TDS pose a variety of health hazards. Irrigation with high TDS resulted in soil salinization and a decrease in macro-porosity but did not decrease crop yields, relative to irrigation with low TDS water. The present study showed that TDS values varied from $1027 \pm 32$ to $1256 \pm 33 \mathrm{mg} / \mathrm{L}$. These values were above the permissible limits of WHO for drinking [25] and below the recommended limit of FAO for irrigation water [28]. The statistical analysis at 95\% confidence level showed no significant differences among the sampling sites. The high value of TDS recorded in the river water might be due to agricultural runoff, discharge of wastes from the town, Ayder referral hospital other human activities like washing of different vehicle at and around the river [35].

Total suspended solids (TSS) include all particles suspended in water which will not pass through a filter. Suspended solids are present in sanitary wastewater and many types of industrial wastewater. There are also nonpoint sources of suspended solids, such as soil erosion from agricultural and construction sites [13]. The present study showed the average value of TSS in the range from $404 \pm 24$ to $509 \pm 20 \mathrm{mg} / \mathrm{L}$. The recorded value of TSS could be due to poor management system of water sources in the city.

Total alkalinity of water is a capacity to neutralize a strong acid and it is normally due to the presence of bicarbonate, carbonate and hydroxide compound of calcium, sodium and potassium [11]. Alkaline soils are difficult to take into agricultural production. Due to the low infiltration capacity, rain water stagnates on the soil easily and, in dry periods, cultivation is hardly possible without copious irrigated water and good drainage. Agriculture is limited to crops tolerant to surface water logging and the productivity is low. The measured TA value from upstream to the downstream of Tsaeda Agam River was varied from $152 \pm 53$ to $331 \pm 63 \mathrm{mg} / \mathrm{L}$. At 95\% confidence level, significance variations was observed in between the sampling sites which could be accounted for the different activities in the river form up to downstream. Among the studied sites, high value of TA recorded in site 2 could be due to the surface runoff from the nearby market areas. Total alkalinity value recorded from the river was also above the permissible limit set by WHO and FAO [25] [28] and thus the river is unsuitable for drinking and irrigation purposes.

Hardness is the property of water which prevents the lather formation with soap and increases the boiling points of water. Hardness of water mainly depends upon the amount of calcium or magnesium salts or both [36]. Based on hardness, water classified into three different categories: soft water ( 0 to $75 \mathrm{mg} / \mathrm{L}$ ), moderately hard water (76 to $150 \mathrm{mg} / \mathrm{L}$ ) and hard water (151 to $300 \mathrm{mg} / \mathrm{L}$ ) [37]. Accordingly, Tsaeda Agam River categorized as hard water. The measured $\mathrm{TH}$ for the studied sites was ranged from $483 \pm 70$ to $778 \pm 44 \mathrm{mg} / \mathrm{L}$. The recorded values of TH for all studied sites, except site 1, were higher than the permissible limit of WHO [25]. The statistical analysis at 95\% confidence limit also showed significant differences among the studied sites which could be due to the various activities occurred at the different site. Thus, our findings indicated that Tsaeda Agam River is unsuitable for drinking purposes.

Calcium and magnesium is directly related to hardness. In the present study, calcium and magnesium contents in mg/L were ranged from $116 \pm 11$ to $270 \pm 12 \mathrm{mg} / \mathrm{L}$ and $87.5 \pm 6.0 \mathrm{mg} / \mathrm{L}$ to $130 \pm 10 \mathrm{mg} / \mathrm{L}$, respectively. The value recorded for calcium was beyond the permissible limit of WHO and FAO for drinking and irrigation water [25, 28]. The value of magnesium, except Site 3 , lies within the recommended value of WHO and FAO. The high value of magnesium recorded in Site 3 could be due to the wastes that receive from Ayder referral hospital indicating that Tsaeda Agam River is unsuitable for drinking and irrigation purposes. 
The chloride concentration serves as an indicator of pollution by sewage. People accustomed to higher chloride in water are subjected to laxative effects [29]. Although chloride is essential to plants in very low amounts, it can cause toxicity to sensitive crops at high concentrations. The values recorded in our study (in $\mathrm{mg} / \mathrm{L}$ ) were in the ranges from $46.2 \pm 6.4$ to $161 \pm 12 \mathrm{mg} / \mathrm{L}$. Thus, the statistical analysis at 95\% confidence level showed significant differences among the studied sites. This might due to the different domestic activities occurred within the city. But, the measured concentrations of chloride ion, except Site 3, lie within the permissible limit of WHO and FAO for drinking and irrigation purposes [25, 28]. The high value recorded at Site 3 might be due to the wastes that receive from Ayder referral hospital showing that waste coming from the referral hospital is polluting the nearby river water.

Sulphate occurs naturally in water as a result of leaching from gypsum and other common minerals. Discharge of industrial wastes and domestic sewage tends to increase its concentration [38]. It is also an important constituent of hardness with calcium and magnesium and is one of the key nutrients in the aquatic environment. Sulfate is relatively common in water and has no major impact on the soil other than contributing to the total salt content. Irrigation water high in sulfate ions reduces phosphorus availability to plants. Since the desired concentration level of sulfate for soil is less than $400 \mathrm{mg} / \mathrm{L}$, higher than this value will acidify the soil [28]. The values determined in our study were in the ranges from $519 \pm 6$ to $921 \pm 22 \mathrm{mg} / \mathrm{L}$, which is higher than the permissible limit set by WHO and FAO [25, 28]. This high value recorded in the studied sites might be due to Mekelle is rich in gypsum and the poor management of municipal waste discharged into the river. The statistical analysis at 95\% confidence level also showed significance differences from site to site. The high value recorded at Site 3 also might be due to different wastes received from domestic and Ayder referral hospital. Thus, Tsaeda Agam River is not suitable for drinking and irrigation purposes.

The nitrogen in water occurs as bound forms like nitrate, nitrite, ammonia and organic forms of nitrogen such as urea, amino acids etc. Total nitrogen is a measure of all forms of nitrogen (organic and inorganic). Nitrogen is an essential plant element and is often the limiting nutrient in marine waters. Nitrates are products of oxidation of organic nitrogen by the bacteria present in soil and water where sufficient oxygen is present. High concentration of nitrates is useful in irrigation but their entry into water resources increase the growth of nuisance algae, macrophytes and trigger eutrophication and pollution [31]. High nitrate concentrations are frequently encountered in treated wastewater, as a result of ammonium nitrogen [39]. Many workers have been reported to have potential health risk from nitrate in drinking water above threshold of $45 \mathrm{mg} / \mathrm{L}$, which may give rise to a condition known as methaemoglobinemia in infants and pregnant women [40]. Natural soil nitrogen or added fertilizers are the usual sources, but nitrogen in the irrigation water has much the same effect as soil-applied fertilizer nitrogen and an excess will cause problems, just as too much fertilizer would. If excessive quantities are present or applied, production of several commonly grown crops may be upset because of overstimulation of growth, delayed maturity or poor quality. The concentration of nitrate in the water samples ranged from $18.3 \pm 5.2$ to $45.5 \pm 1.2 \mathrm{mg} / \mathrm{L}$; the value of nitrite obtained from the river also ranged from $0.03 \pm 0.02$ to $0.39 \pm 0.27 \mathrm{mg} / \mathrm{L}$ and the measured value of ammonium is also in the range of $0.16 \pm 0.01$ to $0.43 \pm 0.19 \mathrm{mg} / \mathrm{L}$. The statistical analysis at $95 \%$ confidence level showed significance differences among the studied sites. Thus, our experimental findings showed the amount of nitrate, nitrite and ammonium were within the permissible limit of WHO and FAO for drinking and irrigation purposes [25, 28]. But, in this study at Site 2 considerable amount total nitrogen $(99.6 \pm 0.2 \mathrm{mg} / \mathrm{L})$ recorded might be due the wastes received from the surface runoff market areas. Thus, the present study indicated that Tsaeda Agam River is free of pollution from nitrogenous materials.

Phosphorous is a limiting nutrient for algal growth and therefore controls the primary productivity of a water body [30]. It is also an essential nutrient and another indicator of anthropogenic biological pollution. High concentrations of phosphate are largely responsible for 
eutrophic conditions in a water body. Eutrophication related problems in warm water systems begin at phosphate concentration of the order 0.34 to $0.70 \mathrm{mg} / \mathrm{L}$ [27]. The mean value soluble phosphorus and total phosphorus recorded in our study were in the ranges from $0.07 \pm 0.00$ to $0.58 \pm 0.38 \mathrm{mg} / \mathrm{L}$ and $0.07 \pm 0.01$ to $0.77 \pm 0.49 \mathrm{mg} / \mathrm{L}$, respectively. The values recorded for both soluble phosphate and total phosphorus, except Site 3, were above the recommended values of WHO and FAO for drinking and irrigation water [25, 28]. The statistical analysis at 95\% confidence level also showed significance differences among the studied sites which could be attributed to the disposal of phosphate containing domestic wastes, agricultural runoff and the wastewater released from Ayder referral hospital. Thus, Tsaeda Agam River is polluted from phosphate containing materials and is not safe for drinking and irrigation purposes.

\section{CONCLUSIONS}

The present investigation conclude that most of the studied physico-chemical parameters are exceeded the permissible limit of WHO for drinking waters but it can be used for irrigation as most of the parameters are within the permissible limit of FAO. Thus, Tsaeda Agam River water has potential for significant improvement in water quality if discharges are minimized by using proper waste disposal of the city dwellers. It is, therefore, regular monitoring of the river and taking suitable remedial measures like collection of domestic sewage and use of proper waste treatment plants should be taken to save the river water from further deterioration. The authors also recommended undertaking further studies in different seasons considering other water quality parameters including heavy metals and trace organic compounds. Regular evaluation of pollutants in the river is also very important.

\section{ACKNOWLEDGEMENTS}

This study was conducted by the use of the research laboratory at Mekelle University, Ethiopia. The authors thank Ato Alem Halefom, Chemistry Department, Mekelle University for his kind help in sample preparation and analysis.

\section{REFERENCES}

1. Fakayode, S.O. Ajeam-Ragee 2005, 10, 1.

2. Khan, M.Y.; Shabeer, M.; Raja, I.A.; Wani, N.A. Globel J. Sci. Front. Res. Interdisciplinary 2012, 12, 1.

3. Altman, S.J.; Parizek, R.R. J. Environ. Qual. 1995, 24, 707.

4. Emongor, V.; Kealotswe, E.; Koorapetse, I.; Sankwasa, S.; Keikanetswe, S. J. Appl. Sci. 2005, 5, 147.

5. Belay, A.; Sahile, S. World Environ. 2013, 3, 29.

6. Sikder, M.T.; Kihara, Y.; Yasuda, M.; Yustiawati; Mihara, Y.; Tanaka, S.; Odgerel, D.; Mijiddorj, B.; Syawal, S.M.; Hosokawa, T.; Saito, T.; Kurasaki, M. Clean Soil Air Water 2013, 41: 60 .

7. Sumok, P. River water quality monitoring: sharing Sarawak experience, 6th Sabah 21 InterAgency Tropical Ecosystem (SITE) Research Seminar, Proceedings, Kota 22 Kinabalu, Malaysia 2001, p. 4.

8. Gebrekidan, M.; Samuel Z. Momona Ethiop. J. Sci. 2011, 3, 105.

9. Akan, C.; Abdulrahman, I.; Oiman, A.; Ogugbuaja, O. Eur. J. Sci. Res. 2008, 23, 122.

10. Singh, M.; Gupt, A.; Beeteswari, K. J. Appl. Sci. Environ. Manage. 2010, 14, 85.

11. Murhekar, G. Res. J. Chem. Sci. 2011, 1, 117. 
12. Aremu, M.; Gav, B.; Opaluwa, O.; Atolaiye, B.; Madu, P.; Sangari, D. Res. J. Chem. Sci. 2011, $1,6$.

13. Rajdeep, K.; Singh V. J. App. Sci. Environ. San. 2011, 6, 385.

14. Ugwu, A.; Wakawa, R. Am. J. Environ. Sci. 2012, 8, 569.

15. Kido, M.; Yustiawati, M.; Syawal, S.; Hosokawa, T.; Tanaka, S.; Saito, T.; Iwakuma, T.; Kurasaki, M. Environ. Monit. Assess. 2009, 156, 317.

16. Borg, H.; Johansson, K. Water, Air, Soil Pollut. 1989, 47, 427.

17. Papafilippaki, A.K.; Kotti, M.E.; Stavroulakis, G.G. Global NEST J. 2008, 10, 320.

18. Lenvik, K.; Steinnes, E.; Pappas, A.C. Nord. Hydrol. 1978, 9, 197.

19. Runnels, D.C.; Shepherd, T.A.; Angino, E.A. Environ. Sci. Technol. 1992, 22, 2316.

20. Turekian, K. K. The Oceans, Streams and Atmosphere, Springer: Berlin; 1969, p 468.

21. Millennium Cities [internet], \{Cited 21/05/2013\}.http://mci.ei.columbia.edu/millenniumcities/mekelle-ethiopia/mekelle-maps-and-population- data/.

22. American Public Health Association, APHA Standard Methods for the Examination of Water and Wastewater, 20th ed., American Public Health Association: Washington D.C.; 1998.

23. Sinha, S.N.; Biswas, M. AJEBS 2011, 2, 18.

24. Government of India and Government of the Netherlands Standard Analytical Procedures for Water Analysis, New Delhi, India; 1999.

25. World Health Organization, WHO Guidelines for Drinking Water, WHO Criteria and Other Supporting Information, World Health Organization: Geneva; 2008.

26. Okweye, P.S. Res. J. Chem. Environ. 2013, 17, 68.

27. Saksena, D.; Kaushik, S. Trophic Status and Habitat Ecology of Entomofauna of Three Water Bodies at Gwalior, Madhya Pradesh in Perspective in Entomological Research, Agarwal, O.P. (Ed.), Scientific Publishers: Jodhpur, India; 1994.

28. Ayers, R.S.; Westcot D.W. Water Quality for Agriculture, FAO Irrigation And Drainage Paper Water: Rome; 1994, p 1.

29. Shrinivasa, R.; Venkateswaralu P. Indian J Environ Prot. 2000, 20, 161.

30. Khan, R.; Jadhav, M.; Ustad, I. Biosci. Discov. 2012, 3, 64.

31. Sinha, S.N.; Biswas, M. Asian J. Exp. Boil. Sci. 2011, 2, 18.

32. Tennessee Valley Authority (TVA). Clean Water Initiative: Volunteer Stream Monitoring Methods Manual, Field Test Draft, TVA: Chattanooga, USA; 1995.

33. Ubwa, S.T.; Atoo, G.H.; Offem, J.O.; Abah, J.; Asemave, K. AJPAC 2013, 7, 131.

34. Dahiya, S.; Kaur, A. J. Environ Poll. 1999, 6, 281.

35. Sonja, C.J. J. Earth Sci. 2010, 21, 876.

36. Trivedy, R.; Goel P. Chemical and Biological Methods for Water Pollution Studies, Environmental Publication, Karad: Maharastra, India; 1986.

37. Soni, H.B.; Dabhi, M.; Thomas, S. IRJC 2013, 3, 69.

38. Manivaskam, N. Physicochemical Examination of Water Sewage and Industrial Effluent, 5th ed., Pragati Prakashan: Meerut, India; 2005.

39. Ali, K.; Javid, A.; Javid, M. Pollution and Industrial Waste, Lahore $6^{\text {th }}$ National Congress Soil Sciences; Lahore, Pakistan; 1996, p 122.

40. Kross, B.C.; Hallberg, G.R.; Bruner, D.R.; Cherryholmes, K.; Johnson, J.K. Am. J. Public Health 1993, 83, 270. 